\title{
Correction to: 'That's What Art Does': Disclosing Religious and Ethical Possibilities Through Film
}

\section{Mikel Burley $^{1}$}

Published online: 19 April 2021

๑) Springer Nature B.V. 2021

\section{Correction to: Sophia}

$$
\text { https://doi.org/10.1007/s11841-020-00794-5 }
$$

The original version of this article unfortunately contained a mistake introduced during the production process.

In the first paragraph, the third sentence should be rewritten as:

As in the case of Prejean's original book, both the film and the play have been widely interpreted as attempts to bolster opposition to the death penalty, and Prejean is well known as an outspoken campaigner for the death penalty's abolition.

The original article has been corrected.

Publisher's Note Springer Nature remains neutral with regard to jurisdictional claims in published maps and institutional affiliations.

The original article can be found online at https://doi.org/10.1007/s11841-020-00794-5.

Mikel Burley

m.m.burley@leeds.ac.uk

1 School of Philosophy, Religion and History of Science, University of Leeds, Leeds LS2 9JT, UK 